\title{
Melatonin Target Proteins: Too Many or Not Enough?
}

\author{
Lei Liu $^{1,2}$, Nedjma Labani ${ }^{1,2}$, Erika Cecon ${ }^{2}$ and Ralf Jockers ${ }^{2 *}$ \\ ${ }^{1}$ Cellular Signaling Laboratory, International Research Center for Sensory Biology and Technology of MOST, Key Laboratory \\ of Molecular Biophysics of Ministry of Education, School of Life Science and Technology, Huazhong University of Science \\ and Technology, Wuhan, China, ${ }^{2}$ Université de Paris, Institut Cochin, CNRS, INSERM, Paris, France
}

\section{OPEN ACCESS}

Edited by:

Hubert Vaudry

Université de Rouen, France

Reviewed by:

Miles Douglas Thompson University of California, San Diego, United States Rostislav Turecek, Academy of Sciences of the Czech Republic (ASCR), Czechia Jean Albert Boutin, Servier, France

*Correspondence: Ralf Jockers ralf.jockers@inserm.fr

Specialty section

This article was submitted to Cellular Endocrinology, a section of the journal Frontiers in Endocrinology

Received: 20 August 2019 Accepted: 30 October 2019 Published: 15 November 2019

Citation:

Liu L, Labani N, Cecon E and Jockers $R$ (2019) Melatonin Target Proteins: Too Many or Not Enough?

Front. Endocrinol. 10:791. doi: 10.3389/fendo.2019.00791
The neurohormone $\mathrm{N}$-acetyl-5-methoxytryptamine, better known as melatonin, is a tryptophan derivative with a wide range of biological effects that is present in many organisms. These effects are believed to rely either on the chemical properties of melatonin itself as scavenger of free radicals or on the binding of melatonin to protein targets. More than 15 proteins, including receptors $\left(\mathrm{MT}_{1}, \mathrm{MT}_{2}\right.$, Mel1c, CAND2, ROR, VDR), enzymes (QR2, MMP-9, pepsin, PP2A, PR-10 proteins), pores (mtPTP), transporters (PEPT1/2, Glut1), and other proteins (HBS, CaM, tubulin, calreticuline), have been suggested to interact with melatonin at sub-nanomolar to millimolar melatonin concentrations. In this review we assemble for the first time the available information on proposed melatonin targets and discuss them in a comprehensive manner to evaluate the robustness of these findings in terms of methodology, physiological relevance, and independent replication.

Keywords: melatonin, GPCR, QR2, ROR, PR-10, MMP-9, PEPT1/2, Glut1

\section{INTRODUCTION}

Melatonin (N-acetyl-5-methoxytryptamine) is an evolutionary ancient molecule that is synthesized by uni- and multicellular organisms, ranging from bacteria, protists, fungi, macroalgae, plants, and animals. Melatonin has been associated with many physiological functions that evolved along the evolutionary time scale (1). Melatonin is a tryptophan derivative that due to its hydrophobicity can cross membranes by passive diffusion (2). The passive diffusion is believed to occur in pinealocytes, specialized cells of the pineal gland in vertebrates that release melatonin during the night, immediately after its circadian synthesis (3). An additional chemical property of melatonin shown in vitro is its antioxidant ability by scavenging free radicals (4). This antioxidant property has been proposed to be the most primitive function of melatonin being relevant along the evolutionary time scale from unicellular organisms, to plants and vertebrates. This aspect has been reviewed in another article of this series (1) and will not be addressed in this article.

Here we will focus on the mechanisms of action of melatonin, more specifically, on those effects that are mediated by its binding to molecular targets. Due to the cell-membrane penetrating properties of melatonin, extra- as well as intracellular proteins were considered as potential melatonin targets since the beginning. Over the years more than 15 different proteins have been proposed to bind melatonin ranging from receptors, enzymes, pore proteins, transporters, and various other proteins (Table 1). Examples of "functional interactions" that are often indirect, i.e., through regulation of gene transcription, including recently discussed examples such as calpain or SIRT3 will not be addressed here (38). 
TABLE 1 | Characteristics of melatonin target proteins.

\begin{tabular}{|c|c|c|c|c|c|c|c|c|c|}
\hline \multirow{2}{*}{$\begin{array}{l}\text { Protein } \\
\text { family }\end{array}$} & \multirow{2}{*}{$\begin{array}{l}\text { Melatonin } \\
\text { target }\end{array}$} & \multirow{2}{*}{$\begin{array}{l}\text { Affinity/Efficacy } \\
\text { for melatonin }\end{array}$} & \multirow[t]{2}{*}{ Effect of melatonin } & \multicolumn{4}{|c|}{ Direct binding of melatonin } & \multirow[t]{2}{*}{ References } & \multirow[t]{2}{*}{ Reviews } \\
\hline & & & & YES/NO & Methodology & Type of binding site & $\begin{array}{l}\text { Independent } \\
\text { replication } \\
\text { (14) }\end{array}$ & & \\
\hline \multirow[t]{6}{*}{ Receptor } & MT1 & $0.1 \mathrm{nM}(\mathrm{Kd})(1)$ & Activation & YES & $\begin{array}{l}\text { Ligand binding, } \\
\text { co-crystal structure }\end{array}$ & $\begin{array}{l}\text { Orthosteric (co-cyrstal, } \\
\text { pharmacol.) }\end{array}$ & YES & $(5,6)$ & $(7,8)$ \\
\hline & MT2 & $0.1 \mathrm{nM}(\mathrm{Kd})(1)$ & Activation & YES & $\begin{array}{l}\text { Ligand binding, } \\
\text { co-crystal structure }\end{array}$ & $\begin{array}{l}\text { Orthosteric (co-cyrstal, } \\
\text { pharmacol.) }\end{array}$ & YES & $(6,9)$ & $(7,8)$ \\
\hline & Mel1c & $1 \mathrm{nM}(\mathrm{Ki})(2)$ & Activation & YES & Ligand binding & $\begin{array}{l}\text { Orthosteric } \\
\text { (pharmacol.) }\end{array}$ & YES & $(10,11)$ & \\
\hline & CAND2 & $10 \mathrm{nM}(\mathrm{Ki})(2)$ & Activation & YES & Ligand binding & Unknown & NO & (12) & \\
\hline & ROR/RZR & $5 \mathrm{nM}(\mathrm{Kd})(3)$ & activation & YES & Ligand binding & unknown & unsuccessful & $(13,14)$ & (15) \\
\hline & VDR & $20 \mu \mathrm{M}(\mathrm{Kd})(4)$ & $\begin{array}{l}\text { Increases affinity of } \\
\text { Runx2 for VDR }\end{array}$ & YES & $\begin{array}{l}\text { Isothermal titration } \\
\text { calorimetry }\end{array}$ & $\begin{array}{l}\text { The C-terminal ligand } \\
\text { binding domain (LBD) } \\
\text { of the VDR }\end{array}$ & NO & (16) & \\
\hline \multirow[t]{4}{*}{ Enzyme } & QR2 & $1 \mu \mathrm{M}(\mathrm{Kd})(4)$ & Inhibition & YES & $\begin{array}{l}\text { Ligand binding, } \\
\text { isothermal titration } \\
\text { calorimetry, co-crystal } \\
\text { structure }\end{array}$ & $\begin{array}{l}\text { Catalytic site } \\
\text { (co-crystal) }\end{array}$ & YES & $(17,18)$ & (19) \\
\hline & MMP-9 & $\begin{array}{l}50-100 \mu \mathrm{M}(\mathrm{IC50}) \\
\text { (5) }\end{array}$ & Inhibition & YES (12) & $\begin{array}{l}\text { Docking studies, } \\
\text { gelatin zymography } \\
\text { assay }\end{array}$ & Catalytic site (docking) & NO & (20) & \\
\hline & Pepsin & $10 \mu \mathrm{M}(\mathrm{Kd})(4)(6)$ & Unknown & YES & $\begin{array}{l}\text { Isothermal titration } \\
\text { calorimetry, equilibrium } \\
\text { microdialysis }\end{array}$ & Catalytic site (docking) & NO & (21) & \\
\hline & PP2A & Unknown & $\begin{array}{l}\text { Suppression of PP2A } \\
\text { inhibitor effect (11) }\end{array}$ & YES (12) & Docking studies & $\begin{array}{l}\text { Near the catalyt sites } \\
\text { (docking) }\end{array}$ & NO & (22) & (23) \\
\hline \multirow[t]{4}{*}{ Transporter } & PEPT1/2 & $0.5-1 \mathrm{mM}(\mathrm{Km})(7)$ & $\begin{array}{l}\text { Transport of melatonin } \\
\text { into cells and } \\
\text { mitochondria }\end{array}$ & YES (12) & Docking studies & $\begin{array}{l}\text { Substrate site } \\
\text { (docking), competion } \\
\text { with classical } \\
\text { substrates }\end{array}$ & NO & (24) & \\
\hline & GLUT1 & Unknown & $\begin{array}{l}\text { Transport of melatonin } \\
\text { into cytoplasm, } \\
\text { mitochondria }\end{array}$ & YES (12) & Docking studies & $\begin{array}{l}\text { Substrate site } \\
\text { (docking), competion } \\
\text { with classical } \\
\text { substrates }\end{array}$ & NO & (25) & (26) \\
\hline & Hyp-1 & $\begin{array}{l}\text { Unknown (low } \\
\text { affinity) }\end{array}$ & $\begin{array}{l}\text { Binding of melatonin } \\
\text { (11) }\end{array}$ & YES & Co-crystal strcuture & $\begin{array}{l}\text { Binding site (2 sites) } \\
\text { (co-crystal) }\end{array}$ & NO (13) & (27) & \\
\hline & LLPR-10.2B & $\begin{array}{l}\text { Unknown (low } \\
\text { affinity) }\end{array}$ & $\begin{array}{l}\text { Binding of melatonin } \\
\text { (11) }\end{array}$ & YES & Co-crystal strcuture & $\begin{array}{l}\text { Binding site (2 sites) } \\
\text { (co-crystal) }\end{array}$ & NO (13) & (28) & \\
\hline Others & mtPTP & $0.8 \mu \mathrm{M}(\mathrm{IC50})(8)$ & $\begin{array}{l}\text { Inhibition of open } \\
\text { propability }\end{array}$ & YES (12) & Electrophysiology & Unknown & NO & (29) & \\
\hline
\end{tabular}


The proposed direct targets of melatonin will be discussed regarding the half-maximal effective concentrations $\left(\mathrm{EC}_{50}\right)$ of melatonin for the referred effects, the affinity of melatonin for the binding sites $\left(\mathrm{K}_{\mathrm{d}}\right)$, and the way melatonin binds to these sites, by resuming any available information on these aspects. The robustness of the proposed targets will be evaluated in terms of independent replication, a criteria that is routinely used in other fields, for example, to confirm the successful deorphanization of G protein-coupled receptors (GPCRs) (39). Finally, we will discuss how the measured $\mathrm{EC}_{50}$ and $\mathrm{K}_{\mathrm{d}}$ values of melatonin for the different targets match with melatonin concentrations reported in different organisms, organs and biological fluids under physiological and pathological/stress conditions.

\section{RECEPTORS}

Receptors have been among the first suspected molecular targets of melatonin $(5,9,10)$. Structural similarity of melatonin, in particular to serotonin and dopamine, and the sensitivity of melatonin-induced pigment aggregation in Xenopus dermal melanophores to the $G_{i / o}$ protein inhibitor pertussis toxin pointed toward 7-transmembrane-spanning GPCRs as likely candidates for melatonin receptors (40). The cell-penetrating properties of melatonin inspired the search for additional, intracellular, melatonin receptors (Table 1).

\section{GPCRs}

GPCRs are currently the best-characterized melatonin targets and are found in invertebrates and vertebrates. These receptors are classified into three groups called $\mathrm{MT}_{1}$ (previously Mel1a), $\mathrm{MT}_{2}$ (Mel1b) and GPR50 (in mammals), or Mellc (in nonmammals) $(5,9,10)$. All these receptors bind melatonin with high affinity (0.1-1 nM) (7) with the exception of GPR50, the mammalian ortholog of Mel1c that lost its ability to bind melatonin during the evolutionary divergence of the therian lineage of mammals from the monotremes $(11,41$, 42). Melatonin is considered to be the natural agonist of these receptors that promotes $G$ protein activation and betaarrestin recruitment. These results have been replicated by many groups. Extensive pharmacological profiles have been established for these receptors with melatonin and also with various synthetic agonistic and antagonistic compounds. In addition, polymorphisms of the $\mathrm{MT}_{1}(43-45)$ and $\mathrm{MT}_{2}$ (4649) receptors have also been identified, some of which affect the binding and signaling properties of these receptors, being factors known to influence both disease risk and/or be of pharmacogenetic relevance $(8,50)$. Progress on these aspects is regularly updated by the International Union of Basic and Clinical Pharmacology (IUPHAR) melatonin receptor subcommittee $(7,8,51)$. Pharmacological studies have been recently complemented by crystallization studies of human $\mathrm{MT}_{1}$ and $\mathrm{MT}_{2}$ receptors co-crystallized with several melatonin analogs in their inactive states (Figures 1A,B) $(52,53)$. Both receptors show a high degree of amino acid homology [55\% overall and $70 \%$ within the transmembrane (TM) domains], and a similar, shallow, melatonin binding pocket located within the TM domains (Figures 1A,B). The binding pose of the melatonin 


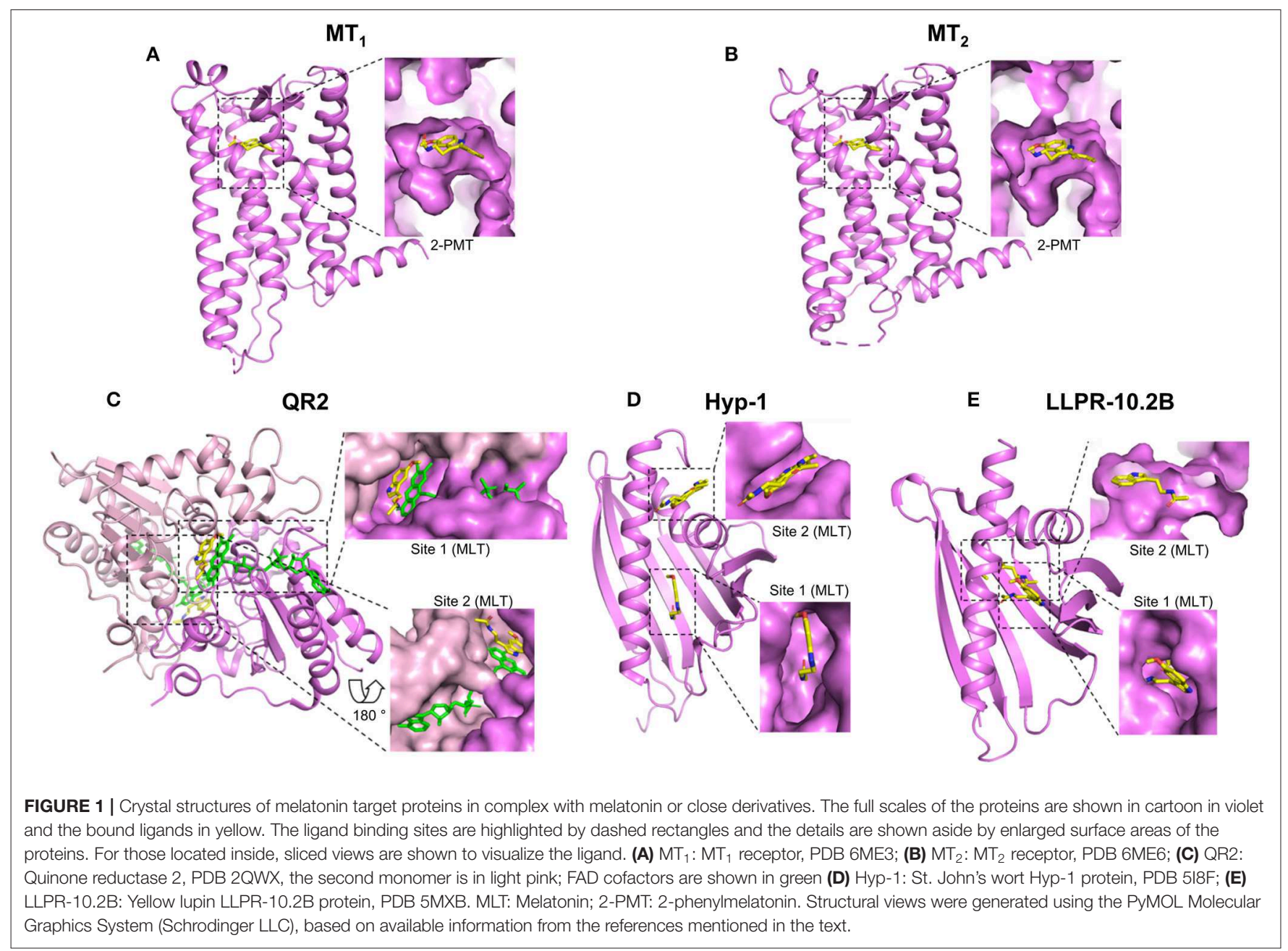

derivative 2-phenylmelatonin (2-PMT) proved to be very similar for both receptors with identical key residues, including the participation of the extracellular loop 2 (ECL2) $\left(\mathrm{N}^{4.60}, \mathrm{~F}^{\mathrm{ECL} 2}\right.$, $\mathrm{Q}^{\mathrm{ECL} 2}$, and $\mathrm{N}^{6.52}$ ) (superscripts represent Ballesteros-Weinstein nomenclature; Figures 1A,B). Interestingly, the binding pocket in the $\mathrm{MT}_{1}$ structure has one lateral ligand entry channel (from the membrane environment), whereas two ligand entry channels, the lateral one, and an additional one from the extracellular side, are visible in the $\mathrm{MT}_{2}$ structure (52-54). These different ligand entry channels as well as their different widths and differences in the overall volume of the pockets with the pocket of $\mathrm{MT}_{2}$ being about $50 \AA^{3}$ larger than that of $\mathrm{MT}_{1}$, offer future opportunities for subtype selective drug development.

Recently, the protein product of the CAND2 gene from Arabidopsis thaliana was proposed to fold into 7-transmembrane domains and to bind the radiolabeled 2-[ $\left.{ }^{125} \mathrm{I}\right]$ iodomelatonin and melatonin with high affinity $\left(\mathrm{K}_{\mathrm{d}}=0.7 \mathrm{nM}\right.$ and $\mathrm{K}_{\mathrm{i}} \sim 10 \mathrm{nM}$, respectively) (12). This recent study has not been replicated independently for the moment. This "phytomelatonin" receptor seems to be totally unrelated to the mammalian melatonin receptors as it shows no significant overall amino acid sequence similarity (around 10\%) nor does it contain any key amino acid residue known to be part of the melatonin binding pocket in melatonin receptors from animals. A pharmacological characterization of this melatonin binding site is still needed in order to compare it with mammalian melatonin receptors.

\section{Nuclear Receptors}

Due to the cell-penetrating property of melatonin, the existence of intracellular receptors has been considered from the beginning. In this context, nuclear melatonin targets attracted much attention. This culminated in the claim that melatonin binds to and activates the retinoic acid receptor-related orphan receptor- $\beta$ (ROR $\beta$ ), a member of the subfamily of retinoid receptors (13). However, these results could not be reproduced by other groups and were retracted later (14). In 2014, the natural ligands for ROR were identified to be sterols and oxysterols including cholesterol and its derivatives, all structurally very different from melatonin $(55,56)$. Despite this compelling negative evidence, it is unfortunate that numerous publications still interpret their melatonin effects by binding of melatonin to RORs and that these interpretations are repeated in many review articles. The current status on nuclear melatonin receptors has been summarized recently by Hardeland, reaching the conclusion that effects of melatonin on nuclear receptors are likely to be rather indirect (15). More recently, the Vitamin D receptor 
(VDR), a nuclear receptor, has been reported to bind melatonin directly with a $\mathrm{K}_{\mathrm{d}}$ of $21.2 \pm 1.9 \mu \mathrm{M}$ (16). The authors found that melatonin binds to the ligand binding domain (LBD) located in the C-terminus of VDR. The binding of melatonin to VDR facilitates the interaction of VDR with the transcription factor Runt-related transcription factor 2 (Runx2), thus promoting the transcriptional activity of Runx 2 indirectly. These results need to be replicated in the future but re-open clearly the long-standing discussion on the possible existence of nuclear melatonin targets.

\section{ENZYMES}

Several enzymes, like the quinone reductase 2, metalloprotease9, pepsin, and protein phosphatase 2 have been proposed to bind melatonin directly (Table 1). There is no apparent similarity between these proteins and their proposed binding sites, and melatonin concentrations necessary for binding vary widely.

\section{Quinone Reductase 2 (QR2)}

QR2 is most likely the best-characterized melatonin target apart from G protein-coupled melatonin receptors (19). The chase for this melatonin target started in 1988 with the identification of the MT3 (also known as ML2) melatonin binding site that was clearly different from the GPCR binding sites (17). This binding site was confirmed independently by several groups. In 2000, 5-methoxycarbonylamino- $\mathrm{N}$-acetyltryptamine (MCANAT), a melatonin derivative with high affinity (nM) for the MT3 binding site and only modest affinity for $\mathrm{MT}_{1}$ and $\mathrm{MT}_{2}$ was used for affinity purification of MT3. The only protein retained was QR2 (57). Expression of QR2 was sufficient to replicate the pharmacology of the MT3 binding site and co-crystals showed that melatonin binds indeed to the catalytic site of QR2 (18) (Figure 1C). Using purified QR2, the $\mathrm{K}_{\mathrm{d}}$ for melatonin was $1 \mu \mathrm{M}$ in isothermal titration calorimetry (ITC) experiments and the inhibitory capacity of melatonin was in the range of $10-130 \mu \mathrm{M}$, depending on the functional assay used to measure QR2 activity (19). The MT3-specific pharmacological profile was recapitulated with purified QR2. The published crystal structure shows that QR2 is a symmetric dimer with two melatonin binding pockets (Figure 1C) at the interface of the two QR2 monomers (18). The poses of the two bound melatonin molecules are similar but not identical in both pockets. Hydrophobic interactions/contacts between melatonin and the protein as well as the $\pi$ interactions between the FAD co-factor, such as the parallel stacking of the melatonin indole moiety on top of the FAD isoalloxazine ring and the melatonin benzene ring on top of the FAD piperazinelike moiety are important elements. QR1 belongs to the drug metabolism enzymes for which the plasticity of the catalytic site is believed to be an inherent property to accommodate natural and synthetic xenobiotic compounds from the environment. A similar broad substrate specificity can be hypothesized for QR2 which evolved from QR1 (58). QR2 has been proposed to be a membrane-associated protein although its presence as a soluble enzyme has also been claimed (19). In conclusion, although there remain some controversies about the subcellular localization of QR2, this enzyme most likely corresponds to the MT3 binding site that binds melatonin in the low $\mu \mathrm{M}$ range.

\section{Metalloproteinase-9 (MMP-9)}

MMP-9 is located in the extracellular matrix (ECM) and contributes to ECM remodeling by cleaving various ECM components. Melatonin has been shown to negatively regulate MMP-9 expression through various mechanisms (see below). An alternative explanation has been proposed based on results obtained with purified MMP-9, which showed an inhibitory effect of melatonin in the gelatin zymography assay with an $\mathrm{IC}_{50}$ of 50$100 \mu \mathrm{M}$, suggesting a direct interaction of melatonin with MMP9 (20). This hypothesis is compatible with molecular docking studies showing that melatonin can bind to a small cleft of MMP-9 that corresponds to its catalytic site (20). Interactions of melatonin with the key residues of the catalytic site of MMP-9 including the three zinc-coordinating histidines were suggested (20). This provides a reasonable explanation for the inhibitory effect of melatonin. MMP-9 has also been co-crystallized with other high-affinity indole-based inhibitors such as phosphinate and carboxylate derivatives $\left(K_{i}=10-200 \mathrm{nM}\right)$ (59). Molecular docking studies with melatonin suggest direct binding of melatonin to MMP-9 but with lower affinity than phosphinate and carboxylate derivatives, most likely because of differences in the pose of the indole rings $(20,59)$. An overall protective effect of melatonin in MMP-9-dependent experimental injury models is observed in several studies including in ethanol- (60) and indomethacin-induced (61) gastric cancer, experimental colitis (62), global cerebral ischemia (63), and in Blood-Brain Barrier permeability (64). The high melatonin concentrations necessary for these effects, either in cellular models $(50-1,000 \mu \mathrm{M})$ or in vivo $(10-100 \mathrm{mg} / \mathrm{kg})$, are compatible with the $\mathrm{IC}_{50}$ of melatonin for purified MMP-9, but raise the question of whether MMP-9 inhibition occurs under physiological conditions or whether it represents a purely experimentally-induced effect.

\section{Pepsin}

Pepsin is a protease that is released in the stomach to catabolize ingested proteins into peptides. The active binding site of pepsin is located in a cleft between the $\mathrm{N}$ - and C-terminal domain with two aspartate residues, Asp32 and Asp215, which are important for its enzymatic activity. A recent biophysical study reported the direct interaction of melatonin with the catalytic site of pepsin with Asp32 being part of the suspected binging pocket (21). Binding occurred at a 1:1 stoichiometry and with a $\mathrm{K}_{\mathrm{d}}$ of $10 \mu \mathrm{M}$ as determined by titration calorimetry and equilibrium microdialysis with recombinant pepsin. Melatonin and pepsin can be both found in relatively high concentrations in the gastrointestinal tract (see below) but their putative relationship is currently unknown. Independent replication of these results has not been reported for the moment.

\section{Phosphoprotein Phosphatase 2A (PP2A)}

PP2A is a member of the Ser/Thr phosphatases subfamily. Inhibition or down-regulation of PP2A promotes hyperphosphorylation of neuronal proteins like Tau, followed by neuronal cell death and neurodegenerative diseases. Melatonin and its derivatives have been reported to be protective in this context (65). Several hypotheses have been put forward to explain the effect of melatonin, including the anti-oxidant activity of 
melatonin and a putative direct interaction of melatonin with PP2A. The latter hypothesis was fueled by the observation that gramine derivatives, which are structurally related to melatonin, suppress the inhibitory effect of okadaic acid on the enzymatic activity of PP2A (22). Docking studies indicated the possible binding of these gramine derivatives near the catalytic site of PP2A (22). A similar scenario was proposed for melatonin in a recent review article (23). Taken together, in the absence of experimental evidence for direct binding of melatonin to PP2A and for an effect of melatonin on the enzymatic activity of PP2A, this enzyme remains a hypothetical melatonin target.

\section{TRANSPORTERS}

Transport proteins help to transport molecules across membrane barriers like the plasma membrane or membranes of intracellular compartments, either passively or actively (against a concentration gradient with an energy cost). Due to its lipophilic properties, melatonin is believed to rapidly distribute all over the body through passive diffusion $(2,66)$. However, differences in the tissue and cellular distribution of melatonin might suggest additional regulated uptake mechanisms (26). Two proteins, the glucose transporter GLUT1 and the oligopeptide transporters PEPT1/2, have been recently proposed to transport melatonin across plasma and mitochondrial membranes (Table 1). In addition, two plant proteins, Hyp-1 and LLPR-10.2B, belonging to the pathogen-response-10 (PR-10) protein family, have been shown to bind and possibly transport melatonin (Table 1).

\section{Glucose Transporter 1 (GLUT1)}

Along this idea of assisted transport of melatonin across membranes, Glut1 was recently proposed to be involved in cellular melatonin uptake (25). GLUT1 levels are particularly high in erythrocytes and also found in the brain, the bloodbrain barrier and other tissues. Pharmacological inhibition of GLUT1 and competition of glucose uptake by high melatonin concentrations (mM), together with molecular docking studies on XylE, an Escherichia coli homolog of GLUT1-4 transporters, suggest that melatonin binds to GLUT1 at a site that overlaps with glucose binding (25). This interesting study will need independent replication and confirmation of direct binding of melatonin to GLUT1. A more detailed characterization of the transport capacity at melatonin concentrations below the $\mathrm{mM}$ range is warranted to appreciate the full physiological relevance of this proposed transport mechanism.

\section{Oligopeptide Transporter 1/2 (PEPT1/2)}

The oligopeptide transporters PEPT1 and PEPT2 are responsible for the uptake of small peptides and peptide-like molecules in the intestine, kidney, and brain. Ectopic expression occurs also in tumors. A recent report shows that PEPT1/2 can improve the basal uptake of melatonin in cells $\left(\mathrm{K}_{\mathrm{m}}=0.5-\right.$ $1 \mathrm{mM}$ ) when applied at $50 \mu \mathrm{M}$ concentration (24). Uptake was competed by several known PEPT1/2 substrates and docking studies suggested interaction of melatonin with key amino acid residues of the binding domain of these transporters. PEPT1/2dependent melatonin uptake was measurable into whole cells and isolated mitochondria. PEPT1/2-dependent and PEPT1/2independent uptakes were equally fast in reaching an equilibrium within 2-3 min, suggesting that the primary impact of PEPT1/2 would be an increase in melatonin uptake capacity of cells at micromolar to millimolar melatonin concentrations. These recent results on PEPT1/2-dependent melatonin uptake have not been replicated independently for the moment. The impact of the PEPT1/2-dependent uptake at low melatonin concentrations remains elusive. Intriguingly, expression of isoform 2 of PEPT1/2 is restricted to pinealocytes, with a pronounced circadian rhythmicity in its expression (100-fold upregulation during the dark phase), suggesting a putative role on the regulation of melatonin synthesis by a so far poorly characterized feedback mechanism (67).

\section{PR-10 Proteins}

Plants are known to produce melatonin (68). Stress evokes a number of defense responses in plants including the expression of specific genes that encode pathogenesis-related (PR) proteins. Members of the PR-10 subclass are structurally characterized by a so-called PR-10-fold and are believed to bind smallmolecule mediators, such as plant hormones. For two PR-10 proteins, Hyp-1 and LLPR-10.2B, the crystal structures in the presence of melatonin have been solved $(27,28)$ (Figures 1D,E). The structures of Hyp-1 and LLPR-10.2B are similar, both assemble the baseball-glove grip shape by a large seven-stranded antiparallel $\beta$-sheet over a long variable $\mathrm{C}$-terminal helix, as well as the two well-defined melatonin binding sites. However, the mode of melatonin binding and the residues that participate in ligand docking are quite different in these two proteins, as the shapes of their binding cavities are not identical (Figures 1D,E). For Hyp-1, binding site 1 is located in an internal cavity of the baseball-glove grip shape and binding site 2 within the external cleft that forms around the V-shaped fork of two $\alpha$ helices. Crystal structure data suggest that melatonin could have two alternative binding modes (see two melatonin molecules positioned in site 2) (Figure 1D). For LLPR-10.2B, both binding sites are within the internal cavity of the baseball-glove grip shape (Figure 1E), and the external melatonin binding site (site 1), not the deeper one (site 2), can be competed by trans-zeatin, a well-characterized PR-10 binding protein.

\section{FURTHER MELATONIN TARGETS}

A range of other melatonin target proteins have been proposed and studied in more or less detail (Table 1).

\section{Serum Albumin}

Early studies showed that melatonin and other methoxyindoles reversibly bind to a high capacity, low affinity binding site in plasma $(30,69)$. Fractionation studies of plasma proteins and in vitro studies with purified plasma proteins identified this binding site as serum albumin (30). Quantitative methods such as isothermal titration calorimetry and absorption spectroscopic with purified albumin revealed a 1:1 (melatonin: albumin) stoichiometry and a binding constant $(\mathrm{Ka})$ of $1 \times 10^{5} \mathrm{~L} \mathrm{~mol}^{-1}$ (31). Albumin fulfills thus the criteria for an efficient carrier 
protein with high binding capacity and low affinity to transport significant amounts of the carrier without interfering with its biological activity.

\section{Mitochondrial Permeability Transition Pore (mtPTP)}

The mtPTP is a multi-protein complex found at the contact site between the inner and outer mitochondrial membrane. Under conditions of oxidative stress, high $\mathrm{Ca}^{2+}$ and low ATP levels, a number of proteins including Bax and Bad are recruited and enable the pore formation at its high conductance state, resulting in the release of $\mathrm{Ca}^{2+}$ into the cytosol. Recording of the mtPTP channel currents from patches of the inner mitochondrial membrane showed a concentration-dependent inhibition of mtPTP currents by melatonin $\left(\mathrm{IC}_{50}=0.8 \mu \mathrm{M}\right)$ (29). These electrophysiological data indicate a direct effect of melatonin on the mtPTP complex. This effect could contribute to the reported anti-apoptotic effects of melatonin, in particular under conditions of transient brain ischemia. This interesting study was not replicated nor followed up for the moment. No more information is available about the identity of the precise melatonin target candidate of the mtPTP complex, which is composed of more than 10 proteins.

\section{Calmodulin (CaM)}

$\mathrm{CaM}$ is a highly conserved $\mathrm{Ca}^{2+}$ binding protein that regulates a large number of $\mathrm{Ca}^{2+}$-dependent signaling events. Studies with various biological sources containing $\mathrm{CaM}$ suggested highaffinity binding of melatonin to $\mathrm{CaM}\left(\mathrm{K}_{\mathrm{d}}=0.2-1 \mathrm{nM}\right)$ (34, 35). Subsequent fluorescence spectroscopy, NMR, and molecular dynamics studies with purified $\mathrm{CaM}$ confirmed the $\mathrm{Ca}^{2+}$. dependent binding of melatonin to $\mathrm{CaM}$, but in a much lower affinity range $(\mathrm{Kd}>2 \mathrm{mM})(32,33)$. The interaction occurs presumably through one of the hydrophobic binding pockets of CaM, which is exposed on the protein surface upon the $\mathrm{Ca}^{2+}$-induced conformational changes. The huge difference (six orders of magnitude) in apparent affinity of melatonin for purified CaM vs. biological samples remains unexplained. Docking studies of melatonin to the $\mathrm{Ca}^{2+}$-CaM-CaM-kinaseII (CaMKII) complex suggest an improved affinity of melatonin for CaM in CaM-effector complexes (36). This is compatible with the observation that the $\mathrm{Ca}^{2+}{ }_{-} \mathrm{CaM}$ complex undergoes an additional conformational change upon interacting with $\mathrm{CaM}$ effector proteins. Further support for the importance of $\mathrm{CaM}$ effector proteins in melatonin binding to $\mathrm{CaM}$ comes from several studies reporting an inhibitory effect of melatonin on the enzymatic activity of CaM effectors such as phosphodiesterases (PDE) $\left(\mathrm{IC}_{50} \sim 1 \mathrm{nM}\right)$ (70), neuronal Nitric-Oxide Synthase (nNOS) $\left(\mathrm{IC}_{50} \sim 1 \mu \mathrm{M}\right)(71,72)$ and CaMKII $\left(\mathrm{IC}_{50} \sim 10 \mathrm{nM}\right)$ (73). The shallow concentration-response curves, spanning 5-6 orders of magnitude, suggest an indirect effect of melatonin on the enzyme activity. For nNOS, the non-competitive behavior and the fact that $\mathrm{CaM}$ antagonists, $\mathrm{Ca}^{2+}$ chelators and an excess of CaM abolish the effect of melatonin on its activity argue for $\mathrm{CaM}$ being the primary melatonin target protein of $\mathrm{nNOS}$ inhibition (72).
Binding of melatonin to microtubules has been suspected very early on (74) and subsequently characterization suggests that at nanomolar concentrations, the cytoskeletal effects of melatonin could be mediated by the $\mathrm{Ca}^{2+}-\mathrm{CaM}$ complex, while at higher concentrations $(10 \mu \mathrm{M})$ "non-specific" binding of melatonin to tubulin occurs (75). These studies were not followed further and the precise nature of the melatonin target protein(s) (tubulin, CaM, other...) remains to be independently confirmed. Alternatively, signaling initiated by $\mathrm{G}$ protein-coupled melatonin receptors could be also responsible for the rearrangement of cytoskeleton proteins $(76,77)$.

In summary, despite the fact that $\mathrm{CaM}$ was among the first melatonin target proteins discovered, the nature of this interaction and its importance are still not clearly defined. Apparent affinities vary widely in the literature, the affinity for the purified $\mathrm{Ca}^{2+}$-CaM complex is low (mM range) and the interesting hypothesis of high-affinity binding of melatonin to $\mathrm{CaM}$ in $\mathrm{Ca}^{2+}-\mathrm{CaM}$ effector complexes is waiting for direct experimental validation.

\section{Calreticulin}

Calreticulin, a ubiquitous and highly conserved $\mathrm{Ca}^{2+}$-binding protein that has chaperon activity and controls intracellular $\mathrm{Ca}^{2+}$ homeostasis, has been purified by melatonin affinity chromatography from nuclear extracts from rat hepatocytes. $2-\left[{ }^{125} \mathrm{I}\right]$ iodomelatonin binding studies with recombinant GST-tagged calreticulin revealed the high-affinity binding of melatonin $\left(\mathrm{K}_{\mathrm{d}}=1 \mathrm{nM}\right)$ that was dependent on $\mathrm{Ca}^{2+}$ and not competed by NAS, 4P-PDOT or luzindole, three G proteincoupled melatonin receptor ligands (37). This biochemical study qualifies calreticulin as a melatonin target candidate that merits independent replication.

\section{EMERGING FEATURES OF MELATONIN BINDING TO ITS TARGETS BASED ON CRYSTAL STRUCTURES}

Melatonin can be divided into three parts based on its chemical structure: the methoxy side chain, the middle indole ring (consisting of a benzene ring fused to a pyrrole ring) and the alkylamide side chain. Among all the published crystal structures of protein complex with melatonin or its close derivatives (Figure 1), the indole ring, in particular the benzene ring, is always involved in the melatonin-protein interaction through hydrophobic contacts or $\pi$ interactions (Table 2). Similarly, the alkylamide side chain often interacts with target proteins (through hydrophobic contacts/hydrogen bonds), with the exception of one of the two bound melatonin molecules in QR2 (Table 2, Figure 1C). In contrast to the alkylamide side chain, the methoxy side chain does not make contacts with the target proteins in most of the cases, with the exception of the high-affinity $\mathrm{MT}_{1}$ and $\mathrm{MT}_{2}$ receptors (Figures $\mathbf{1 A}, \mathbf{B}$ ). This feature, together with the relatively small binding pocket and ligand entry channel, most likely define the structural basis for high-affinity binding of melatonin to these targets $(52,53)$. The binding preference of target proteins for the alkylamide chain 
TABLE 2 | Structural elements of melatonin involved in the interactions with its target proteins.

\begin{tabular}{|c|c|c|c|c|c|c|c|c|c|c|c|c|}
\hline \multirow[t]{2}{*}{ Receptor } & \multirow[t]{2}{*}{ PDB } & \multirow[t]{2}{*}{ Ligand } & \multirow[t]{2}{*}{ Affinity } & \multicolumn{2}{|c|}{ Methoxy } & \multicolumn{2}{|c|}{ Benzene ring } & \multicolumn{2}{|c|}{ Pyrrole ring } & \multicolumn{2}{|c|}{ Alkylamide } & \multirow[b]{2}{*}{$\mathrm{HC}$} \\
\hline & & & & Position & HB & $\mathrm{HC}$ & $\mathrm{Pi}$ & $\mathrm{HC}$ & $\mathrm{Pi}$ & Position & HB & \\
\hline MT1 & 6ME3 & 2-PMT & $\mathrm{nM}$ & Flat & $x$ & $x$ & & & & Down & $x$ & \\
\hline MT2 & 6ME6 & 2-PMT & $\mathrm{nM}$ & Flat & $x$ & $x$ & & & & Down & $x$ & $x$ \\
\hline QR2 & $2 Q W X$ & $\begin{array}{l}\text { Melatonin (site 1) } \\
\text { Melatonin (site 2) }\end{array}$ & $\mu \mathrm{M}$ & $\begin{array}{l}\text { Flat } \\
\text { Flat }\end{array}$ & & $\begin{array}{l}X \\
X\end{array}$ & $\begin{array}{l}X \\
X\end{array}$ & & $x$ & $\begin{array}{l}\text { Up } \\
\text { Down }\end{array}$ & & $x$ \\
\hline Нyp-1 & $518 F$ & $\begin{array}{l}\text { Melatonin (site 1) } \\
\text { Melatonin } 1 \text { (site 2) } \\
\text { Melatonin } 2 \text { (site 2) }\end{array}$ & $\mathrm{mM}$ & $\begin{array}{l}\text { Down } \\
\text { Down } \\
\text { Flat }\end{array}$ & & $\begin{array}{l}x \\
x \\
x\end{array}$ & $\begin{array}{l}X \\
X \\
X\end{array}$ & & $x$ & $\begin{array}{l}\text { Down } \\
\text { Down } \\
\text { Up }\end{array}$ & $x$ & $\begin{array}{l}x \\
x\end{array}$ \\
\hline LLPR-10.2B & $5 \mathrm{M} \times \mathrm{B}$ & $\begin{array}{l}\text { Melatonin (site 1) } \\
\text { Melatonin (site 2) }\end{array}$ & $\mathrm{mM}$ & $\begin{array}{l}\text { Down } \\
\text { Flat }\end{array}$ & & $\begin{array}{l}x \\
x\end{array}$ & & $\begin{array}{l}x \\
x\end{array}$ & $x$ & $\begin{array}{l}\text { Down } \\
\text { Up }\end{array}$ & $\begin{array}{l}x \\
x\end{array}$ & $x$ \\
\hline
\end{tabular}

HB, Hydrogen Bonds; HC, Hydrophobic Contacts; Pi, Pi ( $\pi$ ) Interactions.

might be explained by the high flexibility of this part in respect to the indole ring, thus providing several options for interactions with different proteins ("up" and "down" positions in Table 2). The short methoxy chain apparently prefers to stay within the same plane formed by the indole ring ("flat" position in Table 2) and rotate to the same side like the alkylamide chain in some cases ("down" position in Table 2).

\section{MELATONIN CONCENTRATIONS}

Taken together, more than 15 melatonin target proteins have been proposed (Figure 2) that bind melatonin at very different concentrations-from subnanomolar to millimolar concentrations. This raises the question of whether such a huge range of melatonin concentrations exists to be sensed by the different target proteins. The answer to this question is not trivial since, apart from plasma melatonin levels, there has been a lot of debate about melatonin levels in various organs and organisms, as discussed below briefly.

\section{In Non-vertebrates}

The capacity for melatonin synthesis can be observed in all major taxa studied so far, including bacteria, dinoflagellates and other eukaryotic protists, macroalgae, plants, fungi, and various groups of invertebrate animals. Melatonin concentrations reported suggest important differences between taxa, with some studies reporting values in the upper micromolar range $(26,78)$. This domain suffers from a lack of data replication in the strict sense since studies are rarely performed under identical conditions, as different sources of biological material (different species, locations of collection and environmental conditions, etc.) and methods of sample preparation, melatonin extraction, and melatonin dosage are used.

In plants, more specifically in Arabidopsis thaliana, melatonin is believed to protect against abiotic stress through its antioxidant properties and through its action as plant hormone (68). The protein encoded by the CAND2 gene in Arabidopsis thaliana has been recently shown to be a $G$ protein-coupled receptor for melatonin that regulates stomatal closure through a $\mathrm{H}_{2} \mathrm{O}_{2}$ and $\mathrm{Ca}^{2+}$ signaling pathway (12). Interestingly, $\mathrm{K}_{\mathrm{i}}$ values for melatonin are in the range of $10 \mathrm{nM}$, which are of high affinity and likely to be reached under physiological and/or stress conditions. The importance of melatonin in plants is further supported by genetic manipulation of the genes of melatonin biosynthesis as upregulation of melatonin synthesis yields improved tolerance abilities, enabling plants to better survive under hostile environmental conditions (79). The physiological relevance of melatonin binding to $\mathrm{PR}-10$ proteins, the other plant proteins reported to bind melatonin, remains elusive as $\mathrm{K}_{\mathrm{d}}$ values are in the $\mathrm{mM}$ range.

Significant melatonin levels in plants and other sources raise the question of the impact of dietary sources of melatonin (80). Many studies report melatonin content of $\sim 1 \mathrm{ng} / \mathrm{mL}$, however big variations are reported as well $(81,82)$. Several studies reported the impact of dietary melatonin from fruits on human serum melatonin levels (83), however the effects remained modest and should be also considered in light of the endogenous production of melatonin in the gastrointestinal tract (GIT) and its absence of contribution to circulating melatonin levels (see below).

\section{In Vertebrates}

Plasma melatonin levels vary considerably between different animals and even on an individual level. In addition, melatonin levels can be altered under certain conditions, as demonstrated in humans. Indeed, there is a decline in melatonin levels with age and under several diseases, meaning that the establishment of a reference for melatonin concentration is not straightforward. In mammals including humans melatonin is produced in a circadian manner with plasma daytime melatonin levels around $5 \mathrm{pg} / \mathrm{mL}$ or less and nighttime levels rising up to $100-150 \mathrm{pg} / \mathrm{mL}(\sim 0.65 \mathrm{nM})$ (84). At this concentration range, the only confirmed melatonin targets are the GPCRs, $\mathrm{MT}_{1}$, $\mathrm{MT}_{2}$, and Mel1c (Figure 2). Potential candidates are calreticulin (single study still awaiting independent confirmation) and CaMeffector complexes (still awaiting experimental validation of docking predictions). In vertebrates, the pineal gland has been identified as the primary site of rhythmic melatonin synthesis that determines plasma melatonin levels. Pineal melatonin is 


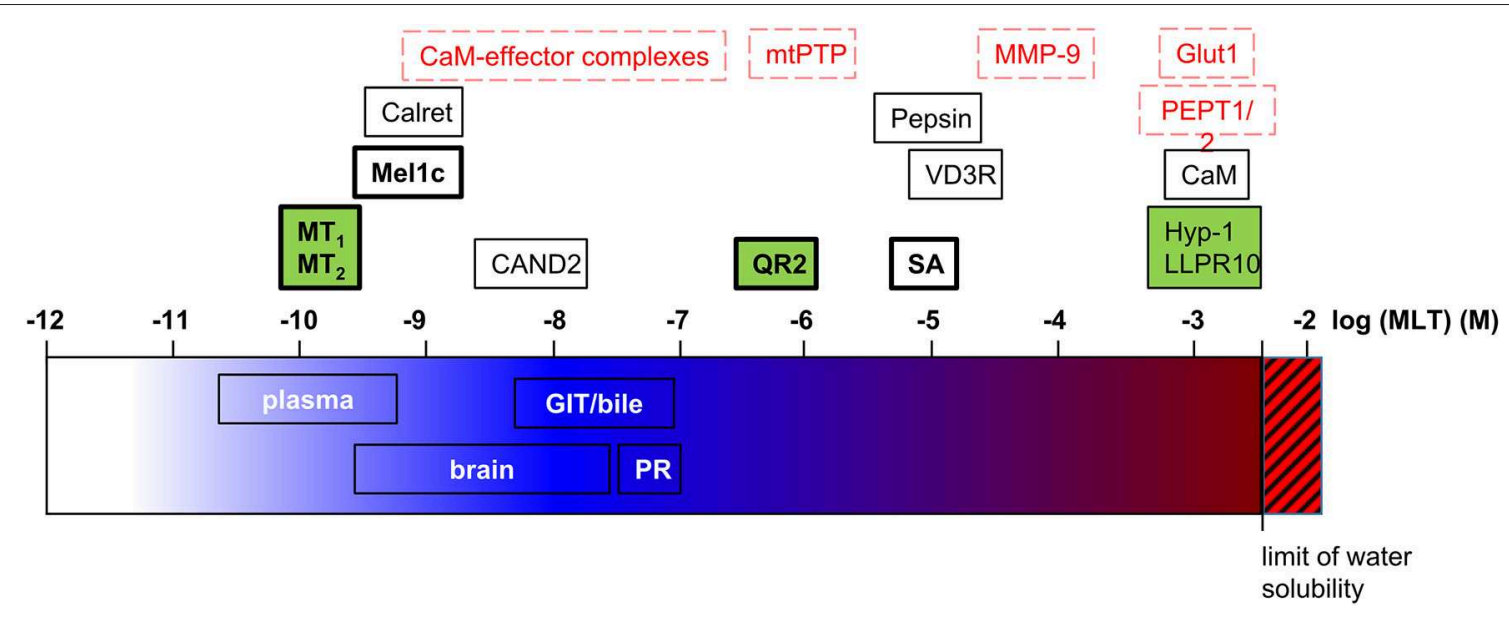

FIGURE 2 | Melatonin target proteins and melatonin concentrations. Melatonin target proteins are positioned on the log scale of molar melatonin concentrations according to their affinity/efficacy for melatonin. The range of melatonin concentrations measured in biological fluids and tissues are indicated on the same scale. Legend for melatonin target proteins: black letters, demonstrated direct targets; red letters, suggested direct targets (docking, functional studies); bold letters, findings were independently replicated; green background, co-crystal structures with melatonin or phenyl-melatonin available. Calret, calreticulin; GIT, gastrointestinal tract; MLT, melatonin; PR, pineal recess; SA, serum albumin.

released in the peripheral circulation via the vein of Galen in the cerebrospinal fluid (CSF) directly via the pineal recess (PR), an evagination of the third ventricle in contact with pinealocytes. In the $\mathrm{PR}$, nighttime melatonin concentrations of $20,000 \mathrm{pg} / \mathrm{mL}(90 \mathrm{nM})$ have been detected in sheep (85). Melatonin is then spread over the brain through the CSF from which it penetrates into the different tissues generating a melatonin gradient from the periventricular to the most distal cerebral tissues ranging from 17 to $0.35 \mathrm{nM}$ at night (86). Interestingly, whereas melatonin levels vary in a circadian manner in periventricular tissues, like in the plasma, the variation was only marginal in brain tissues more distal from ventricles. The melatonin concentrations of $300 \mathrm{pM}$ measured at these locations would be still sufficient to activate $\mathrm{MT}_{1}$ and $\mathrm{MT}_{2}$ receptors. Taken together, even though the highest melatonin levels close to the pineal gland are up to 100 times higher (up to $90 \mathrm{nM}$ ) compared to plasma levels, no obvious additional melatonin targets to the abovementioned ones have been identified so far (Figure 2). The three candidates getting the closest in terms of melatonin affinity/efficiency are QR2, VDR, and mtPTP $(1-20 \mu \mathrm{M})$ [see (87) for review on QR2]. Since melatonin levels reported above are mean values, it cannot be excluded at present that higher melatonin levels can be reached locally, in specific sub-regions and on the subcellular level (see below). In addition, the highly diffusible nature of melatonin, being released right after its synthesis, also makes it difficult to estimate its concentration at a specific location at a given time.

Apart from the pineal gland, several other sources of melatonin synthesis have been described in vertebrates (26). The retina is the second tissue where melatonin production follows a circadian rhythm, similarly to the pinealocytes. Melatonin production from all other extrapineal sources is not rhythmic and does not contribute to the plasma levels of melatonin. Maybe the highest reported extrapineal melatonin levels are in the bile and in enterochromaffin-like cells of the GIT reaching levels that are 10-100 times higher than plasma levels (up to $50 \mathrm{nM}$ ) (88-91). Why these significant sources of melatonin do not contribute to circulating melatonin levels remains unclear. Considering local effects of melatonin in these organs, it can be assumed that reported melatonin levels bind a similar repertoire of potential melatonin targets as detailed above for the CSF and the brain. Whether melatonin levels measured in the GIT are sufficient to bind to pepsin $\left(\mathrm{K}_{\mathrm{d}}=10 \mu \mathrm{M}\right)$ in the stomach remains to be demonstrated.

Extrapineal melatonin production has also been reported from immune cells where it occurs in an inducible manner. For example, mononuclear cells from human blood activated by zymosan or by Escherichia coli produce melatonin in the order of hundreds of $\mathrm{pg} / \mathrm{mL}(\sim 1 \mathrm{nM})$, which in turn modulates the phagocytic activity of these cells by an autocrine action mediated by melatonin receptors (92-94). Human lymphocytes, rodent peritoneal macrophages, bone marrow-derived dendritic cells and the macrophage cell line RAW 264.7 also have been reported to produce melatonin in response to diverse stimuli, including lipopolysaccharides from bacteria, serum from tumorbearing animal models, and adrenergic stimulation (92, 9598). Similar to what was previously mentioned about melatonin from the GIT, it is also not clear why melatonin produced by these cells does not impact the overall circulating level of melatonin.

A significant number of people take exogenous melatonin. In the USA, an estimated 3.1 million adults (1.3\% of the adult population) take melatonin on a daily basis (99). Melatonin is popular for the promotion of improved sleep initiation and fast adjustment in situations of circadian misalignment (such as jet-lag when traveling over several time zones), but also as a prophylactic anti-aging treatment and as a preventive 
treatment for neurodegenerative diseases and cancer. Typical doses of melatonin range from 0.3 to $10 \mathrm{mg}$ per day (100). At a dose of 0.3 and $2 \mathrm{mg}$ of melatonin, plasma peak levels increase 2 to 3 times over endogenous peak levels, respectively $(84,101)$. In critically ill patients with a reduced disappearance rate of melatonin, as well as in normal healthy subjects, administration of 3 and $5 \mathrm{mg}$ was reported to increase plasma peak levels 7 to 15 times reaching levels of $\sim 50-100 \mathrm{nM}$ (102, 103). It can be therefore anticipated that maximal serum peak levels of melatonin will not reach far beyond $100 \mathrm{nM}$ even upon treatment with melatonin, which is $\sim 200$ times higher than endogenous peak levels and in the range of melatonin levels reported in the brain and GIT/bile. Taken together, exogenous administration of melatonin increases plasma peak level up to 200 times, but is unlikely to reach $\mu \mathrm{M}$ or $\mathrm{mM}$ concentrations to bind to additional, low-affinity target proteins in vivo.

\section{At the Subcellular Level}

Several reports suggest that melatonin might be differentially distributed in subcellular compartments. In particular, cell nuclei and mitochondria seem to contain higher melatonin concentrations than other compartments such as the cytosol. Side-by-side comparison of melatonin and serotonin using amperometric and fluorescence measurement methods in intact cells demonstrated that extracellular melatonin, but not serotonin, equilibrates within seconds with the cytoplasm confirming that melatonin crosses biological membranes rapidly (2). Other studies suggest facilitation of melatonin transport, in particular into mitochondria, through PEPT1/2 and GLUT1 transporters (26). Recently, mitochondria isolated from neurons have been proposed to synthesize melatonin but the levels reached are unknown (104). The relative contribution of pineal melatonin synthesis to mitochondrial melatonin levels in neurons, i.e., whether melatonin is imported in or exported out of mitochondria and whether this occurs by passive diffusion or through the proposed PEPT1/2 and GLUT1 transporters, remain interesting questions to be solved in the future. The presence of melatonin in mitochondria is not only of interest because of the presumed elimination of free radicals by the antioxidant action of melatonin but also because of the presence of $\mathrm{MT}_{1}$ receptors in mitochondrial membranes coupled to the inhibition of cytochrome $\mathrm{c}$ release and apoptosis (104, 105).

Similar to mitochondria, nuclei have been proposed to contain melatonin targets. As detailed before, its nature remains to be determined in light of the inconclusive evidence for ROR $\beta$ and follow-up studies on VDR will show the robustness of this recently proposed nuclear melatonin target. The presence of $\mathrm{MT}_{1}$ or $\mathrm{MT}_{2}$ receptors in the nuclear membrane cannot be completely ruled out either in analogy to other GPCRs with nuclear localization. Alternatively, calreticulin present in ER membranes could be also of relevance due to the close spatial proximity of the ER membrane and the nuclear envelop.
Altogether, the subcellular distribution of locally produced melatonin and its targets are still an active and challenging object of study in the melatonin field. Progress in this field holds great promise to solve much of the mystery regarding the mismatch between melatonin concentrations required to bind to melatonin target proteins and the in situ concentrations measured so far.

\section{CONCLUSION}

Currently 18 different melatonin targets have been proposed comprising receptors, enzymes, transporters and other proteins (Table 1). Surprisingly, 12 of them are still awaiting independent replication. The level of melatonin to which these targets respond range over 7 orders of magnitude, from subnanomolar to millimolar concentrations (Figure 2). Only 8 of the validated/proposed targets respond to low to moderate melatonin levels. For 5 melatonin targets, structural information is available from co-crystals. These targets provide first insights on the structural requirements for melatonin binding as they bind melatonin with high $(\mathrm{nM})$, medium $(\mu \mathrm{M})$, and low $(\mathrm{mM})$ affinity concentrations. More studies will be necessary to validate the proposed targets by independent replication. Pharmacological profiles will have to be established similar to what has been done for melatonin receptors already starting back in 1975 (106). Further studies will also be necessary to determine local melatonin production and melatonin concentrations with more precision, directly at their targets in specific cellular environments and in intracellular compartments, to judge the relevance of melatonin and its targets with $\mu \mathrm{M}$ and $\mathrm{mM}$ affinity/efficacy. Development of non-invasive detection methods will be beneficial in this respect to capture the real levels of the highly diffusible melatonin. The authors hope that this review will provide a rational basis for a consensus of validated melatonin target proteins and help to eliminate ungrounded claims about melatonin targets, in particularly in the review literature of the melatonin field.

\section{AUTHOR CONTRIBUTIONS}

$\mathrm{RJ}$ initiated the review and wrote the first draft together with LL and EC. The initial literature research was performed by NL. All the authors participated in the editing of the manuscript and in the preparation of the figures and tables. LL generated structural models shown in Figure 1 and defined structural requirements of melatonin binding shown in Table 2 .

\section{FUNDING}

This work was supported by grants from the Fondation Recherche Médicale (Equipe FRM 2019, EQU201903008055 to RJ), Agence Nationale de la Recherche (ANR- ANR-19-CE16 MitoGPCR to RJ), Inserm and CNRS. 


\section{REFERENCES}

1. Zhao D, Yu Y, Shen Y, Liu Q, Zhao Z, Sharma R, et al. Melatonin synthesis and function: evolutionary history in animals and plants. Front Endocrinol. (2019) 10:249. doi: 10.3389/fendo.2019.00249

2. Yu H, Dickson EJ, Jung SR, Koh DS, Hille B. High membrane permeability for melatonin. J Gen Physiol. (2016) 147:63-76. doi: 10.1085/jgp.201511526

3. Simonneaux V, Ribelayga C. Generation of the melatonin endocrine message in mammals: a review of the complex regulation of melatonin synthesis by norepinephrine, peptides, and other pineal transmitters. Pharmacol Rev. (2003) 55:325-95. doi: 10.1124/pr.55.2.2

4. Tan DX, Reiter RJ, Manchester LC, Yan MT, El-Sawi M, Sainz RM, et al. Chemical and physical properties and potential mechanisms: melatonin as a broad spectrum antioxidant and free radical scavenger. Curr Top Med Chem. (2002) 2:181-97. doi: 10.2174/1568026023394443

5. Reppert SM, Godson C, Mahle CD, Weaver DR, Slaugenhaupt SA, Gusella JF. Molecular characterization of a second melatonin receptor expressed in human retina and brain: the $\mathrm{Mel}(\mathrm{1b})$ melatonin receptor. Proc Natl Acad Sci USA. (1995) 92:8734-8. doi: 10.1073/pnas.92.19.8734

6. Browning C, Beresford I, Fraser N, Giles H. Pharmacological characterization of human recombinant melatonin $\mathrm{mt}(1)$ and $\mathrm{MT}(2)$ receptors. Br J Pharmacol. (2000) 129:877-86. doi: 10.1038/sj.bjp.0703130

7. Dubocovich ML, Delagrange P, Krause DN, Sugden D, Cardinali DP, Olcese J. International Union of Basic and Clinical Pharmacology. LXXV Nomenclature, classification, and pharmacology of G proteincoupled melatonin receptors. Pharmacol Rev. (2010) 62:343-80. doi: $10.1124 /$ pr. 110.002832

8. Jockers R, Delagrange P, Dubocovich ML, Markus RP, Renault N, Tosini $\mathrm{G}$, et al. Update on melatonin receptors. IUPHAR review. Br J Pharmacol. (2016) 173:2702-25. doi: 10.1111/bph.13536

9. Reppert SM, Tsai T, Roca AL, Sauman I. Cloning of a structural and functional homolog of the circadian clock gene period from the giant silkmoth Antheraea pernyi. Neuron. (1994) 13:1167-76. doi: 10.1016/0896-6273(94)90054-X

10. Ebisawa T, Karne S, Lerner MR, Reppert SM. Expression cloning of a highaffinity melatonin receptor from Xenopus dermal melanophores. Proc Natl Acad Sci USA. (1994) 91:6133-7. doi: 10.1073/pnas.91.13.6133

11. Gautier C, Guenin SP, Riest-Fery I, Perry TJ, Legros C, Nosjean $\mathrm{O}$, et al. Characterization of the Mel1c melatoninergic receptor in platypus (Ornithorhynchus anatinus). PLoS ONE. (2018) 13:e0191904. doi: 10.1371/journal.pone.0191904

12. Wei J, Li DX, Zhang JR, Shan C, Rengel Z, Song ZB, et al. Phytomelatonin receptor PMTR1-mediated signaling regulates stomatal closure in Arabidopsis thaliana. J Pineal Res. (2018) 65:e12500. doi: 10.1111/jpi.12500

13. Becker-Andre M, Wiesenberg I, Schaeren WN, Andre E, Missbach M, Saurat $\mathrm{JH}$, et al. Pineal gland hormone melatonin binds and activates an orphan of the nuclear receptor superfamily. J Biol Chem. (1994) 269:28531-4.

14. Becker-Andre M, Schaeren-Wiemers N, Andre E, Wiesenberg I, Missbach M, Saurat JH, et al. Erratum (Correction and Addition) to: pineal gland hormone melatonin binds and activates an orphan of the nuclear receptor superfamily. J Biol Chem. (1997) 272:16707. doi: 10.1074/jbc.272.26.16707

15. Hardeland R. Melatonin and retinoid orphan receptors: demand for new interpretations after their exclusion as nuclear melatonin receptors. Melatonin Res. (2018) 1:78-93. doi: 10.32794/mr11250005

16. Fang N, Hu C, Sun W, Xu Y, Gu Y, Wu L, et al. Identification of a novel melatonin-binding nuclear receptor: vitamin D receptor. J Pineal Res. (2019) 20:e12618. doi: 10.1111/jpi.12618

17. Duncan MJ, Takahashi JS, Dubocovich ML. 2-[125I]iodomelatonin binding sites in hamster brain membranes: pharmacological characteristics and regional distribution. Endocrinology. (1988) 122:1825-33. doi: 10.1210/endo-122-5-1825

18. Calamini B, Santarsiero BD, Boutin JA, Mesacar AD. Kinetic, thermodynamic and X-ray structural insights on the interaction of melatonin and analogs with quinone reductase 2. Biochem J. (2008) 413:81-91. doi: 10.1042/BJ20071373

19. Boutin JA, Ferry G. Is there sufficient evidence that the melatonin binding site MT3 is quinone reductase 2? J Pharmacol Exp Ther. (2019) 368:59-65. doi: $10.1124 /$ jpet.118.253260
20. Rudra DS, Pal U, Maiti NC, Reiter RJ, Swarnakar S. Melatonin inhibits matrix metalloproteinase- 9 activity by binding to its active site. J Pineal Res. (2013) 54:398-405. doi: 10.1111/jpi.12034

21. Li $\mathrm{X}, \mathrm{Ni} \mathrm{T}$. Binding of glutathione and melatonin to pepsin occurs via different binding mechanisms. Eur Biophys J. (2016) 45:165-74. doi: 10.1007/s00249-015-1085-y

22. Lajarin-Cuesta R, Nanclares C, Arranz-Tagarro JA, Gonzalez-Lafuente L, Arribas RL, Araujo De Brito M, et al. Gramine derivatives targeting $\mathrm{Ca}(2+)$ channels and Ser/Thr phosphatases: a new dual strategy for the treatment of neurodegenerative diseases. J Med Chem. (2016) 59:6265-80. doi: 10.1021/acs.jmedchem.6b00478

23. Arribas RL, Romero A, Egea J, De Los Rios C. Modulation of serine/threonine phosphatases by melatonin: therapeutic approaches in neurodegenerative diseases. Br J Pharmacol. (2018) 175:3220-9. doi: 10.1111/bph.14365

24. Huo X, Wang C, Yu Z, Peng Y, Wang S, Feng S, et al. Human transporters, PEPT1/2, facilitate melatonin transportation into mitochondria of cancer cells: an implication of the therapeutic potential. J Pineal Res. (2017) 62:e12390. doi: 10.1111/jpi.12390

25. Hevia D, Gonzalez-Menendez P, Quiros-Gonzalez I, Miar A, RodriguezGarcia A, Tan DX, et al. Melatonin uptake through glucose transporters: a new target for melatonin inhibition of cancer. J Pineal Res. (2015) 58:234-50. doi: $10.1111 /$ jpi. 12210

26. Mayo JC, Aguado A, Cernuda-Cernuda R, Alvarez-Artime A, Cepas V, Quiros-Gonzalez I, et al. Melatonin uptake by cells: an answer to its relationship with glucose? Molecules. (2018) 23:e1999. doi: 10.3390/molecules23081999

27. Sliwiak J, Dauter Z, Jaskolski M. Crystal structure of Hyp-1, a Hypericum perforatum PR-10 protein, in complex with melatonin. Front Plant Sci. (2016) 7:668. doi: 10.3389/fpls.2016.00668

28. Sliwiak J, Sikorski M, Jaskolski M. PR-10 proteins as potential mediators of melatonin-cytokinin cross-talk in plants: crystallographic studies of LlPR-10.2B isoform from yellow lupine. FEBS J. (2018) 285:1907-22. doi: $10.1111 /$ febs. 14455

29. Andrabi SA, Sayeed I, Siemen D, Wolf G, Horn T. Direct inhibition of the mitochondrial permeability transition pore: a possible mechanism responsible for antiapoptotic effects of melatonin. FASEB J. (2004) 18:86971. doi: 10.1096/fj.03-1031fje

30. Cardinali DP, Lynch HJ, Wurtman RJ. Binding of melatonin to human and rat plasma proteins. Endocrinology. (1972) 91:1213-8. doi: 10.1210/endo-91-5-1213

31. Li X, Wang S. Binding of glutathione and melatonin to human serum albumin: a comparative study. Colloids Surf B Biointerfaces. (2015) 125:96103. doi: 10.1016/j.colsurfb.2014.11.023

32. Turjanski AG, Estrin DA, Rosenstein RE, Mccormick JE, Martin SR, Pastore A, et al. NMR and molecular dynamics studies of the interaction of melatonin with calmodulin. Protein Sci. (2004) 13:2925-38. doi: 10.1110/ps.04611404

33. Ouyang H, Vogel HJ. Melatonin and serotonin interactions with calmodulin: NMR, spectroscopic and biochemical studies. Biochim Biophys Acta. (1998) 1383:37-47. doi: 10.1016/S0167-4838(97)00157-X

34. Benitez-King G, Huerto-Delgadillo L, Anton-Tay F. Binding of 3H-melatonin to calmodulin. Life Sci. (1993) 53:201-7. doi: 10.1016/0024-3205(93)90670-X

35. Romero MP, Garciaperganeda A, Guerrero JM, Osuna C. Membrane-bound calmodulin in Xenopus laevis oocytes as a novel binding site for melatonin. FASEB J. (1998) 12:1401-8. doi: 10.1096/fasebj.12.13.1401

36. Landau M, Zisapel N. The low affinity binding of melatonin to calmodulin: use of computational methods to explain its physiological relevance. In: Pandi-Perumal SR, Cardinali DP, editors. In Melatonin-From Molecules to Therapy. New York, NY: Nova Science (2007). p. 69-79.

37. Macias M, Escames G, Leon J, Coto A, Sbihi Y, Osuna A, et al. Calreticulinmelatonin. An unexpected relationship. Eur J Biochem. (2003) 270:832-40. doi: 10.1046/j.1432-1033.2003.03430.x

38. Mayo JC, Sainz RM, Gonzalez Menendez P, Cepas V, Tan DX, Reiter RJ. Melatonin and sirtuins: A "not-so unexpected" relationship. J Pineal Res. (2017) 62:e12391. doi: 10.1111/jpi.12391

39. Davenport AP, Alexander SP, Sharman JL, Pawson AJ, Benson $\mathrm{HE}$, Monaghan $\mathrm{AE}$, et al. International Union of Basic and 
Clinical Pharmacology. LXXXVIII G protein-coupled receptor list: recommendations for new pairings with cognate ligands. Pharmacol Rev. (2013) 65:967-86. doi: 10.1124/pr.112.007179

40. Morgan P, Barret P, Howell H, Helliwel R. Melatonin receptors:localization, molecular pharmacology and physiological significance. Neurochem Int. (1994) 24:101-46. doi: 10.1016/0197-0186(94) 90100-7

41. Dufourny L, Levasseur A, Migaud M, Callebaut I, Pontarotti P, Malpaux B, et al. GPR50 is the mammalian ortholog of Mellc: evidence of rapid evolution in mammals. BMC Evol Biol. (2008) 8:105. doi: 10.1186/1471-2148-8-105

42. Clement N, Renault N, Guillaume JL, Cecon E, Journe AS, Laurent X, et al. Importance of the second extracellular loop for melatonin MT1 receptor function and absence of melatonin binding in GPR50. Br J Pharmacol. (2017) 175:3281-97. doi: 10.1111/bph.14029

43. Barrett P, Conway S, Jockers R, Strosberg AD, Guardiola LB, Delagrange P, et al. Cloning and functional analysis of a polymorphic variant of the ovine Mel 1a melatonin receptor. Biochim Biophys Acta. (1997) 1356:299-307. doi: 10.1016/S0167-4889(96)00179-6

44. Chaste P, Clement N, Mercati O, Guillaume JL, Delorme R, Botros HG, et al. Identification of pathway-biased and deleterious melatonin receptor mutants in autism spectrum disorders and in the general population. PLOS ONE. (2010) 5:e11495. doi: 10.1371/journal.pone.0011495

45. Chaste P, Clement N, Botros HG, Guillaume JL, Konyukh M, Pagan C, et al. Genetic variations of the melatonin pathway in patients with attention-deficit and hyperactivity disorders. J Pineal Res. (2011) 51:394-9. doi: 10.1111/j.1600-079X.2011.00902.x

46. Bouatia-Naji N, Bonnefond A, Cavalcanti-Proenca C, Sparso T, Holmkvist $\mathrm{J}$, Marchand M, et al. A variant near MTNR1B is associated with increased fasting plasma glucose levels and type 2 diabetes risk. Nat Genet. (2009) 41:89-94. doi: 10.1038/ng.277

47. Lyssenko V, Nagorny CL, Erdos MR, Wierup N, Jonsson A, Spegel P, et al. Common variant in MTNR1B associated with increased risk of type 2 diabetes and impaired early insulin secretion. Nat Genet. (2009) 41:82-8. doi: 10.1038/ng.288

48. Prokopenko I, Langenberg C, Florez JC, Saxena R, Soranzo N, Thorleifsson G, et al. Variants in MTNR1B influence fasting glucose levels. Nat Genet. (2009) 41:77-81. doi: 10.1038/ng.290

49. Bonnefond A, Clément N, Fawcett K, Yengo L, Vaillant E, Guillaume $\mathrm{JL}$, et al. Rare MTNR1B variants impairing melatonin receptor 1B function contribute to type 2 diabetes. Nat Genet. (2012) 44:297-301. doi: 10.1038/ng.1053

50. Thompson MD, Cole DE, Capra V, Siminovitch KA, Rovati GE, Burnham WM, et al. Pharmacogenetics of the G protein-coupled receptors. Methods Mol Biol. (2014) 1175:189-242. doi: 10.1007/978-1-4939-0956-8_9

51. Dubocovich ML, Cardinali DP, Delagrange P, Krause DN, Strosberg D, Sugden D, et al. Melatonin Receptors. The IUPHAR Compendium of Receptor Characterization and Classification. London: IUPHAR Media (2001). p. 270-7.

52. Johansson LC, Stauch B, Mccorvy JD, Han GW, Patel N, Huang XP, et al. XFEL structures of the human MT2 melatonin receptor reveal the basis of subtype selectivity. Nature. (2019) 569:289-92. doi: 10.1038/s41586-019-1144-0

53. Stauch B, Johansson LC, Mccorvy JD, Patel N, Han GW, Huang XP, et al. Structural basis of ligand recognition at the human MT1 melatonin receptor. Nature. (2019) 569:284-8. doi: 10.1038/s41586-019-1141-3

54. Cecon E, Liu L, Jockers R. Melatonin receptor structures shed new light on melatonin research. J Pineal Res. (2019) 67:e12606. doi: 10.1111/jpi.12606

55. Slominski AT, Kim TK, Takeda Y, Janjetovic Z, Brozyna AA, Skobowiat C, et al. RORalpha and ROR gamma are expressed in human skin and serve as receptors for endogenously produced noncalcemic 20-hydroxy- and 20,23dihydroxyvitamin D. FASEB J. (2014) 28:2775-89. doi: 10.1096/fj.13-242040

56. Slominski AT, Zmijewski MA, Jetten AM. RORalpha is not a receptor for melatonin (response to DOI 10.1002/bies.201600018). Bioessays. (2016) 38:1193-4. doi: 10.1002/bies.201600204

57. Nosjean O, Ferro M, Cogé F, Beauverger P, Henlin JM, Lefoulon F, et al. Identification of the melatonin-binding site MT3 as the quinone reductase 2. J Biol Chem. (2000) 275:31311-7. doi: 10.1074/jbc.M005141200
58. Zhao Q, Yang XL, Holtzclaw WD, Talalay P. Unexpected genetic and structural relationships of a long-forgotten flavoenzyme to NAD(P)H:quinone reductase (DT-diaphorase). Proc Natl Acad Sci USA. (1997) 94:1669-74. doi: 10.1073/pnas.94.5.1669

59. Tochowicz A, Maskos K, Huber R, Oltenfreiter R, Dive V, Yiotakis A, et al. Crystal structures of MMP-9 complexes with five inhibitors: contribution of the flexible Arg424 side-chain to selectivity. J Mol Biol. (2007) 371:989-1006. doi: 10.1016/j.jmb.2007.05.068

60. Swarnakar S, Mishra A, Ganguly K, Sharma AV. Matrix metalloproteinase9 activity and expression is reduced by melatonin during prevention of ethanol-induced gastric ulcer in mice. J Pineal Res. (2007) 43:56-64. doi: 10.1111/j.1600-079X.2007.00443.x

61. Ganguly K, Maity P, Reiter RJ, Swarnakar S. Effect of melatonin on secreted and induced matrix metalloproteinase- 9 and -2 activity during prevention of indomethacin-induced gastric ulcer. J Pineal Res. (2005) 39:307-15. doi: 10.1111/j.1600-079X.2005.00250.x

62. Esposito E, Mazzon E, Riccardi L, Caminiti R, Meli R, Cuzzocrea S. Matrix metalloproteinase- 9 and metalloproteinase- 2 activity and expression is reduced by melatonin during experimental colitis. J Pineal Res. (2008) 45:166-73. doi: 10.1111/j.1600-079X.2008.00572.x

63. Kim SJ, Lee SR. Protective effect of melatonin against transient global cerebral ischemia-induced neuronal cell damage via inhibition of matrix metalloproteinase-9. Life Sci. (2014) 94:8-16. doi: 10.1016/j.lfs.2013. 11.013

64. Alluri H, Wilson RL, Anasooya Shaji C, Wiggins-Dohlvik K, Patel S, Liu $\mathrm{Y}$, et al. Melatonin preserves blood-brain barrier integrity and permeability via matrix metalloproteinase-9 inhibition. PLoS ONE. (2016) 11:e0154427. doi: 10.1371/journal.pone.0154427

65. Montilla-Lopez P, Munoz-Agueda MC, Feijoo Lopez M, Munoz-Castaneda JR, Bujalance-Arenas I, Tunez-Finana I. Comparison of melatonin versus vitamin C on oxidative stress and antioxidant enzyme activity in Alzheimer's disease induced by okadaic acid in neuroblastoma cells. Eur J Pharmacol. (2002) 451:237-43. doi: 10.1016/S0014-2999(02)02151-9

66. Reiter RJ, Tan DX, Kim SJ, Cruz MH. Delivery of pineal melatonin to the brain and SCN: role of canaliculi, cerebrospinal fluid, tanycytes and Virchow-Robin perivascular spaces. Brain Struct Funct. (2014) 219:1873-87. doi: 10.1007/s00429-014-0719-7

67. Bailey MJ, Coon SL, Carter DA, Humphries A, Kim JS, Shi Q, et al. Night/day changes in pineal expression of $>600$ genes: central role of adrenergic/cAMP signaling. J Biol Chem. (2009) 284:7606-22. doi: 10.1074/jbc.M808394200

68. Arnao MB, Hernandez-Ruiz J. Melatonin: a new plant hormone and/or a plant master regulator? Trends Plant Sci. (2019) 24:38-48. doi: $10.1016 /$ j.tplants.2018.10.010

69. Laud CA, Smith I. The binding of methoxyindoles to human plasma proteins. Prog Brain Res. (1979) 52:513-5. doi: 10.1016/S0079-6123(08)62958-1

70. Benitez KG, Huerto DL, Anton TF. Melatonin modifies calmodulin cell levels in MDCK and N1E-115 cell lines and inhibits phosphodiesterase activity in vitro. Brain Res. (1991) 557:289-92. doi: 10.1016/0006-8993(91)90146-M

71. Pozo D, Reiter RJ, Calvo JR, Guerrero JM. Inhibition of cerebellar nitric oxide synthase and cyclic GMP production by melatonin via complex formation with calmodulin. J Cell Biochem. (1997) 65:430-42. doi: 10.1002/(SICI)10974644(19970601)65:3<430::AID-JCB12>3.0.CO;2-J

72. Leon J, Macias M, Escames G, Camacho E, Khaldy H, Martin M, et al. Structure-related inhibition of calmodulin-dependent neuronal nitric-oxide synthase activity by melatonin and synthetic kynurenines. Mol Pharmacol. (2000) 58:967-75. doi: 10.1124/mol.58.5.967

73. Benitez KG, Rios A, Martinez A, Anton TF. In vitro inhibition of $\mathrm{Ca} 2+/$ calmodulin-dependent kinase II activity by melatonin. Biochim Biophys Acta. (1996) 1290:191-6. doi: 10.1016/0304-4165(96)00025-6

74. Cardinali DP, Freire F. Melatonin effects on brain. Interaction with microtubule protein, inhibition of fast axoplasmic flow and induction of crystaloid and tubular formations in the hypothalamus. Mol Cell Endocrinol. (1975) 2:317-30. doi: 10.1016/0303-7207(75)90019-2

75. Huerto-Delgadillo L, Anton-Tay F, Benitez-King G. Effects of melatonin on microtubule assembly depend on hormone concentration: role of melatonin as a calmodulin antagonist. J Pineal Res. (1994) 17:55-62. doi: 10.1111/j.1600-079X.1994.tb00114.x 
76. Bondi CD, Mckeon RM, Bennett JM, Ignatius PF, Brydon L, Jockers R, et al. MT1 melatonin receptor internalization underlies melatonin-induced morphologic changes in Chinese hamster ovary cells and these processes are dependent on Gi proteins, MEK 1/2 and microtubule modulation. J Pineal Res. (2008) 44:288-98. doi: 10.1111/j.1600-079X.2007.00525.x

77. Dupre C, Bruno O, Bonnaud A, Giganti A, Nosjean O, Legros C, et al. Assessments of cellular melatonin receptor signaling pathways: beta-arrestin recruitment, receptor internalization, and impedance variations. Eur J Pharmacol. (2018) 818:534-44. doi: 10.1016/j.ejphar.2017.11.022

78. Hardeland R. Melatonin, hormone of darkness and more: occurrence, control mechanisms, actions and bioactive metabolites. Cell Mol Life Sci. (2008) 65:2001-18. doi: 10.1007/s00018-008-8001-x

79. Kanwar MK, Yu J, Zhou J. Phytomelatonin: recent advances and future prospects. J Pineal Res. (2018) 65:e12526. doi: 10.1111/jpi.12526

80. Meng X, Li Y, Li S, Zhou Y, Gan RY, Xu DP, et al. Dietary sources and bioactivities of melatonin. Nutrients. (2017) 9:e367. doi: 10.3390/nu90 40367

81. Mercolini L, Mandrioli R, Raggi MA. Content of melatonin and other antioxidants in grape-related foodstuffs: measurement using a MEPS-HPLC-F method. J Pineal Res. (2012) 53:21-8. doi: 10.1111/j.1600-079X.2011.00967.x

82. Tan DX, Zanghi BM, Manchester LC, Reiter RJ. Melatonin identified in meats and other food stuffs: potentially nutritional impact. J Pineal Res. (2014) 57:213-8. doi: 10.1111/jpi.12152

83. Sae-Teaw M, Johns J, Johns NP, Subongkot S. Serum melatonin levels and antioxidant capacities after consumption of pineapple, orange, or banana by healthy male volunteers. J Pineal Res. (2013) 55:58-64. doi: 10.1111/jpi.12025

84. Zhdanova IV, Wurtman RJ, Balcioglu A, Kartashov AI, Lynch HJ. Endogenous melatonin levels and the fate of exogenous melatonin: age effects. J Gerontol A Biol Sci Med Sci. (1998) 53:B293-8. doi: 10.1093/gerona/53A.4.B293

85. Tricoire H, Locatelli A, Chemineau P, Malpaux B. Melatonin enters the cerebrospinal fluid through the pineal recess. Endocrinology. (2002) 143:8490. doi: 10.1210/endo.143.1.8585

86. Legros C, Chesneau D, Boutin JA, Barc C, Malpaux B. Melatonin from cerebrospinal fluid but not from blood reaches sheep cerebral tissues under physiological conditions. J Neuroendocrinol. (2014) 26:151-63. doi: 10.1111/jne.12134

87. Boutin JA. Quinone reductase 2 as a promising target of melatonin therapeutic actions. Expert Opin Ther Targets. (2016) 20:303-17. doi: 10.1517/14728222.2016.1091882

88. Tan DX, Manchester LC, Reiter RJ, Qi WB, Hanes MA, Farley NJ. High physiological levels of melatonin in the bile of mammals. Life Sci. (1999) 65:2523-9. doi: 10.1016/S0024-3205(99)00519-6

89. Bubenik GA. Thirty four years since the discovery of gastrointestinal melatonin. J Physiol Pharmacol. (2008) 59(Suppl. 2):33-51.

90. Acuña-Castroviejo D, Escames G, Venegas C, Díaz-Casado ME, LimaCabello E, López LC, et al. Extrapineal melatonin: sources, regulation, and potential functions. Cell Mol Life Sci. (2014) 71:2997-3025. doi: 10.1007/s00018-014-1579-2

91. Bertrand PP, Polglaze KE, Bertrand RL, Sandow SL, Pozo MJ. Detection of melatonin production from the intestinal epithelium using electrochemical methods. Curr Pharm Des. (2014) 20:4802-6. doi: 10.2174/1381612819666131119105421

92. Carrillo-Vico A, Lardone PJ, Fernandez-Santos JM, Martin-Lacave I, Calvo JR, Karasek M, et al. Human lymphocyte-synthesized melatonin is involved in the regulation of the interleukin-2/interleukin-2 receptor system. J Clin Endocrinol Metab. (2005) 90:992-1000. doi: 10.1210/jc. 2004-1429
93. Pontes GN, Cardoso EC, Carneiro-Sampaio MM, Markus RP. Injury switches melatonin production source from endocrine (pineal) to paracrine (phagocytes) - melatonin in human colostrum and colostrum phagocytes. $J$ Pineal Res. (2006) 41:136-41. doi: 10.1111/j.1600-079X.2006.00345.x

94. Pires-Lapa MA, Tamura EK, Salustiano EM, Markus RP. Melatonin synthesis in human colostrum mononuclear cells enhances dectin-1mediated phagocytosis by mononuclear cells. J Pineal Res. (2013) 55:240-6. doi: 10.1111/jpi.12066

95. Carrillo VA, Calvo JR, Abreu P, Lardone PJ, Garcia MS, Reiter RJ, et al. Evidence of melatonin synthesis by human lymphocytes and its physiological significance: possible role as intracrine, autocrine, and/or paracrine substance. FASEB J. (2004) 18:537-9. doi: 10.1096/fj.03-0694fje

96. Martins EJr, Ferreira AC, Skorupa AL, Afeche SC, Cipolla-Neto J, Costa Rosa LF. Tryptophan consumption and indoleamines production by peritoneal cavity macrophages. J Leukoc Biol. (2004) 75:1116-21. doi: $10.1189 /$ jlb.1203614

97. Maldonado MD, Mora-Santos M, Naji L, Carrascosa-Salmoral MP, Naranjo MC, Calvo JR. Evidence of melatonin synthesis and release by mast cells. Possible modulatory role on inflammation. Pharmacol Res. (2010) 62:282-7. doi: 10.1016/j.phrs.2009.11.014

98. Pires-Lapa MA, Carvalho-Sousa CE, Cecon E, Fernandes PA, Markus RP. $\beta$ adrenoceptors trigger melatonin synthesis in phagocytes. Int J Mol Sci. (2018) 19. doi: 10.3390/ijms19082182

99. Clarke TC, Black LI, Stussman BJ, Barnes PM, Nahin RL. Trends in the use of complementary health approaches among adults: United States, 2002-2012. Natl Health Stat Rep. (2015) 10:1-16.

100. Karamitri A, Jockers R. Melatonin in type 2 diabetes mellitus and obesity. Nat Rev Endocrinol. (2018) 15:105-25. doi: 10.1038/s41574-018-0130-1

101. Zisapel N. New perspectives on the role of melatonin in human sleep, circadian rhythms and their regulation. Br J Pharmacol. (2018) 175:3190-9. doi: 10.1111/bph.14116

102. Deacon S, Arendt J. Melatonin-induced temperature suppression and its acute phase-shifting effects correlate in a dose-dependent manner in humans. Brain Res. (1995) 688:77-85. doi: 10.1016/0006-8993(95)96872-I

103. Mistraletti G, Sabbatini G, Taverna M, Figini MA, Umbrello M, Magni P, et al. Pharmacokinetics of orally administered melatonin in critically ill patients. $J$ Pineal Res. (2010) 48:142-7. doi: 10.1111/j.1600-079X.2009.00737.x

104. Suofu Y, Li W, Jean-Alphonse FG, Jia J, Khattar NK, Li J, et al. Dual role of mitochondria in producing melatonin and driving GPCR signaling to block cytochrome c release. Proc Natl Acad Sci USA. (2017) 114:E7997-8006. doi: 10.1073/pnas.1705768114

105. Gbahou F, Cecon E, Viault G, Gerbier R, Jean-Alphonse F, Karamitri A, et al. Design and validation of the first cell-impermeant melatonin receptor agonist. Br J Pharmacol. (2017) 174:2409-21. doi: 10.1111/bph.13856

106. Heward CB, Hadley ME. Structure-activity relationships of melatonin and related indoleamines. Life Sci. (1975) 17:1167-77. doi: 10.1016/0024-3205(75)90340-9

Conflict of Interest: The authors declare that the research was conducted in the absence of any commercial or financial relationships that could be construed as a potential conflict of interest.

Copyright (c) 2019 Liu, Labani, Cecon and Jockers. This is an open-access article distributed under the terms of the Creative Commons Attribution License (CC BY). The use, distribution or reproduction in other forums is permitted, provided the original author(s) and the copyright owner(s) are credited and that the original publication in this journal is cited, in accordance with accepted academic practice. No use, distribution or reproduction is permitted which does not comply with these terms. 